\title{
LIFE-HISTORY TRAITS OF THE INVASIVE POPULATION OF PRUSSIAN CARP, CARASSIUS GIBELIO (ACTINOPTERIGI: CYPRINIFORMES: CYPRINIDAE), FROM GELINGÜLLÜ RESERVOIR, YOZGAT, TURKEY
}

\author{
Şerife Gülsün KIRANKAYA* and F. Güler EKMEKÇİ \\ Hydrobiology Section, Department of Biology, Faculty of Science, Hacettepe University, Ankara, Turkey
}

\begin{abstract}
Kırankaya Ş.G., Ekmekçi F.G. 2013. Life-history traits of the invasive population of Prussian carp, Carassius gibelio (Actinopterigi: Cypriniformes: Cyprinidae), from Gelingüllü Reservoir, Yozgat, Turkey. Acta Ichthyol. Piscat. 43 (1): 31-40.
\end{abstract}

Background. Prussian carp, Carassius gibelio (Bloch, 1782), is one of the successful invaders of freshwater systems of Turkey. Although, Prussian carp has rapidly expanded its area of distribution in Anatolia during the last two decades, there is limited information about its biological features in new environments. In order to determine the impact of invasive species on ecosystem, the life history characteristics of an exotic fish species in different locations should be monitored. The presently reported study provides information about the growth and reproduction of Prussian carp introduced into a reservoir in Central Anatolia.

Materials and methods. Age, growth, and reproduction of Prussian carp were studied during a 3-year period in Gelingüllü Reservoir, Kızılırmak River Basin. A total of 344 specimens were caught by gill nets. Age was determined from scales. Length-weight relation, von Bertalanffy equation, and specific growth rate were used to evaluate the fish growth. In order to assess growth and reproduction patterns, fecundity, GSI, and variations in oocyte size were determined.

Results. Both males and females reached a maximum age of 5+ years. Fork length was 6-27 cm in males and 5.6-26.8 $\mathrm{cm}$ in females. Both sexes matured during their second year of life (1+ year). In the Gelingüllü Reservoir population the males were predominant the overall sex ratio was $1: 0.73$ (193 males to 139 females) and differed significantly from unity. The von Bertalanffy growth equation was $L_{t}=32.17\left(1-e^{-0.232(t-0.094)}\right) \mathrm{cm}$ for males and $L_{t}=36.03\left(1-e^{-0.212(t-0.205)}\right) \mathrm{cm}$ for females. Growth in length was approximately $70 \%$ in males and $85 \%$ in females during the first year of life. The somatic condition of the fish increased markedly during late spring and summer. A prolonged spawning period was observed from April to August. Maximum egg diameter was $1.51 \mathrm{~mm}$ and maximum absolute fecundity was 174000 oocytes.

Conclusion. Compared to previously published data, the studied Prussian carp population was characterized by more rapid growth during the first year of life, earlier maturity, higher fecundity, and a shorter life span. These life history characteristics are typical of invasive species.

Keywords: Prussian carp, gibel carp, non-native fish, longevity, growth, fecundity, Anatolia

\section{INTRODUCTION}

The genus Carassius includes carp-like species that are widely distributed throughout Europe and Asia. A total of four Carassius species have been reported from Europe: goldfish, C. auratus (L.); crucian carp, C. carassius (L.); Prussian carp, C. gibelio (Bloch, 1782); and ginbuna, C. langsdorfii Temminck et Schlegel, 1846 (see Kalous et al. 2007, Takada et al. 2010, Froese and Pauly 2012), but according to Kottelat and Freyhof (2007) there are some doubts about the establishment of $C$. langsdorfii in Europe. Crucian carp, C. carassius, is native to European waters; however, the natural distribution of $C$. gibelio remains unclear; some researchers suggest that it is natu- rally distributed in central and eastern Europe, Siberia, Korea, and northeast China (Szczerbowski 2001, Kottelat and Freyhof 2007). Recently a neotype of $C$. gibelio have been designated based on a specimen from central Europe (Kalous et al. 2012).

Prussian carp, C. gibelio, was first recorded in the Thrace region of Turkey in 1986 (Özuluğ et al. 2004). According to some new records of this species in Turkey, it can be concluded that Prussian carp has rapidly expanded its area of distribution in Anatolia during the last two decades (Şaşı and Balık 2003, Kalous et al. 2004, Özuluğ et al. 2004, İlhan et al. 2005, Özuluğ et al. 2005a, b, Gaygusuz et al. 2007). As in many European countries,

\footnotetext{
${ }^{*}$ Correspondence: (present address): Dr Şerife Gülsün Kırankaya, Biyoloji Bölümü, Fen Edebiyat Fakültesi, Düzce Üniversitesi, Konuralp Yerleşkesi, 81620 Düzce, Turkey, phone: (+90) 380 5412404, fax: (+90) 380 5412403, e-mail: gkirankaya@gmail.com.
} 
Prussian carp is today widespread in Turkey because it is commonly stocked either accidentally or intentionally together with Cyprinus carpio, which is introduced, in particular, into artificial water bodies to support commercial or recreational fisheries (Özuluğ et al. 2004, Tarkan et al. 2006).

Prussian carp easily becomes a dominant species in stagnant- and slow-running water, and may change the flow of nutrients in the entire ecosystem (Tsoumani et al. 2006). The density of native species is also adversely affected by Prussian carp introductions (Tarkan et al. 2012b). Therefore, it has been considered as one of the most dangerous newcomers to native fish communities (Crivelli 1995, Kalous et al. 2004). Freshwater ecosystems are seriously imperilled by the spread of non-native fishes thus establishing profiles of their life-history characteristics in an emerging tool for developing conservation and management strategies (Ribeiro et al. 2008). In order to determine the impact of invasive organisms on native species and on ecosystem functioning, more observational and experimental studies are needed. Monitoring the life history characteristics of an invasive fish species in different locations is a part of such research (García-Berthou 2007). To prevent the spread and establishment of new populations of Prussian carp, and to remove it from previously invaded environments, its biological characteristics should be determined in different habitats.

In Turkey, the Prussian carp has been poorly studied and very little biological information is available. Comparison of some biological parameters of a given species in different ecosystems allows us to support opinions about the influence of environment on species growth. The aim of the presently reported study was to describe the growth and reproduction of Prussian carp introduced into a reservoir in Central Anatolia.

\section{MATERIALS AND METHODS}

Study area. Fish specimens were caught from Gelingüllü Reservoir, Yozgat, Central Anatolia $\left(35^{\circ} 032^{\prime} 02^{\prime \prime} \mathrm{E}\right.$, $\left.39^{\circ} 36^{\prime} 30^{\prime \prime} \mathrm{N}\right)$. The reservoir was created for irrigation purposes at the end of 1993 on the tributaries (Kanak and Eğriöz) of the Kizılırmak River. The reservoir is elevated $1050 \mathrm{~m}$ above the sea level and continental climatic conditions typical of Central Anatolia prevail in the region. According to mean temperature values for 1997-2003, the maximum and minimum air temperatures in the area were $19.6{ }^{\circ} \mathrm{C}$ in August and $-2{ }^{\circ} \mathrm{C}$ in January, respectively. While the water temperature varied between 8 and $10^{\circ} \mathrm{C}$ within the $5 \mathrm{~m}$ water layer below the surface in the spring, it reached $20^{\circ} \mathrm{C}$ during summer. Water temperature was approximately $5^{\circ} \mathrm{C}$ throughout the autumn and the water surface-especially in shallow parts of the reservoir - was covered with ice in winter. Due to the climatic conditions in the region, fishing is possible only from March to November. Dissolved oxygen content of the water was $11 \mathrm{mg} \cdot \mathrm{L}^{-1}$ in spring, but during summerespecially in the deeper (around $5 \mathrm{~m}$ ) parts of the water column - it was below the critical level of $5 \mathrm{mg} \cdot \mathrm{L}^{-1}$ for cyprinids. The water was slightly alkaline and $\mathrm{pH}$ ranged from 7.9 to 9.2 . Electrical conductivity of the water varied from 423 to $636 \mu \mathrm{S} \cdot \mathrm{cm}^{-1}$ (Kirankaya unpublished*).

The native ichthyofauna of the area consists of Capoeta baliki Turan, Kottelat, Ekmekçi et Imamoglu, 2006; C. sieboldii (Steindachner, 1864); Squalius cephalus (L.); Chondrostoma nasus (L.); Alburnus sp.; Alburnoides bipunctatus (Bloch, 1782); Rhodeus amarus (Bloch, 1782); Barbus tauricus Kessler, 1877; Cobitis simplicispina Hankó, 1925; and Oxynoemacheilus brandtii (Kessler, 1877). After the reservoir dam was constructed, a warm water culture fish-mirror carp (form of Cyprinus carpio L.) - was introduced into the reservoir between 1994 and 2001 to provide employment opportunity, as had been done in other reservoirs in Turkey. During 2001-2004 both scaled carp and mirror carp (forms of Cyprinus carpio) were introduced into the reservoir. Following these stocking activities, exotic species, such as Prussian carp; topmouth gudgeon, Pseudorasbora parva (Temminck et Schlegel, 1846); and big-scale sand smelt, Atherina boyeri Risso, 1810 were observed in the reservoir.

Collection and identification of fish. During the period of June 2002-July 2005, monthly sampling was performed, except during the unfavourable winter season. A total of 344 Prussian carp specimens were collected using gill nets varying in mesh size from $20 \times 20 \mathrm{~mm}$ up to $100 \times 100 \mathrm{~mm}$ with the aid of local professional fishermen. The fish captured were killed using an overdose of 2-phenoxyethanol and subsequently examined. The key to species of Carassius in Europe given by Kottelat and Freyhof (2007) was used for the identification of Carassius gibelio.

Methods for collecting biological data. Fork length (FL) and total length (TL) were measured to the nearest $0.5 \mathrm{~cm}$ and wet body weight $(W)$ was measured to the nearest $0.1 \mathrm{~g}$. Age was determined by scale reading. Scales below the first ray of the dorsal fin and above the lateral line were removed, placed between two slides after cleaning with $4 \% \mathrm{KOH}$, and read under a binocular microscope independently by two researchers (Lagler 1966).

Mean length at age data were used to estimate the von Bertalanffy growth parameters: $L_{t}=L_{\text {inf }}\left(1-e^{-k(t-t 0)}\right)$, where $L_{t}$ is the FL of fish at time $t, L_{\text {inf }}$ is the asymptotic FL, $k$ is the rate at which the asymptotic length is approached, and $t_{0}$ is the hypothetical age at $L_{t}=0$.

The relation between FL [cm] and $W[\mathrm{~g}]$ was estimated separately for males and females using log-transformed data. Differences in length-weight relation curves were compared between males and females, and to evaluate the growth curve the variation of the coefficient $b$ from 3 was determined using Student's $t$-test (Zar 1999).

The specific growth rate $(G)$ (Wootton 1990) was calculated as follows:

$$
\begin{aligned}
G_{L} & =\left(\log _{e} L_{2} \cdot L_{1}{ }^{-1}\right) t^{-1} \\
G_{W} & =\left(\log _{e} W_{2} \cdot W_{1}^{-1}\right) t^{-1}
\end{aligned}
$$

where: $G_{L}$ is the length growth rate, $G_{W}$ is weight growth rate, $L_{2}$ and $W_{2}$ are final $L$ and final $W$, respectively, $L_{1}$ and $W_{1}$ are initial $L$ and $W$, respectively, and $t$ is time interval.

\footnotetext{
* Kırankaya Ş.G. 2007. Gelingüllü Baraj Gölü’ndeki (Yozgat) aynalı sazan, pullu sazan (Cyprinus carpio L., 1758) ve gümüşi havuz balığı [Carassius gibelio (Bloch, 1758)]'nın büyüme, üreme ve beslenme biyolojisinin karşılaştırmalı olarak incelenmesi. [A comperative study on growth, reproduction and feeding biology of mirror carp, wild carp (Cyprinus carpio L., 1758) and Prussian carp [Carassius gibelio (Bloch, 1758)] in Gelingüllü Dam Lake (Yozgat-Turkey).] PhD Thesis, Institute of Science, Hacettepe University, Ankara, Turkey. [In Turkish.]
} 
Fulton's condition factor $(K)$ was calculated monthly using the equation (Lagler 1966):

$$
K=W \cdot \mathrm{FL}^{-3}
$$

Nested ANOVA was used to determine the significance of difference in $K$ between sexes and years. Sex was determined by visual examination of gonads. The sex ratio was determined using the chi-square $\left(\chi^{2}\right)$ test (Zar 1999). Gonads were removed and weighed to the nearest $0.01 \mathrm{~g}$, and ovaries were preserved in $4 \%$ formaldehyde solution. Temporal patterns in gonad development were described using the gonadosomatic index (GSI), based on the equation:

$$
\mathrm{GSI}=100 \mathrm{GW} \cdot W^{-1}
$$

where: GW is gonad weight and $W$ is total body weight. Mean GSI values were calculated monthly from March to November. GSI was compared between sexes by nested ANOVA (Zar 1999).

Age and length at first maturity were determined according to the logistic regression model, using the following equations:

and

$$
P_{\mathrm{m}}=\left(1+e^{[-r(t-t \mathrm{~m})]}\right)^{-1}
$$

$$
P_{\mathrm{m}}=\left(1+e^{[-r(L-L \mathrm{~m})]}\right)
$$

where: $P_{\mathrm{m}}$ is the rate [\%] of mature fish in each age and length group, $L$ is the mean value $[\mathrm{cm}]$ of each length group, $L_{\mathrm{m}}$ is the shortest length [cm] of the mature fish comprising at least $50 \%$ all fish at this length, $t$ is the age group, $t_{\mathrm{m}}$ is the youngest age (year) of the mature fish comprising at least $50 \%$ of all fish of this age, and $r$ is the curve of the logistic function (King 1996).

Mature ovaries were sub-sampled ( $1 \mathrm{~g}$ ) from the anterior, middle, and posterior portions of each ovarian lobe, and then the eggs were examined under a stereomicroscope. Egg diameter was measured using PC-based image analysis BAB-Bs200Pro (Ankara, Turkey) software. Eggs were classified into 3 groups, according to colour and size as immature, maturing, and mature (Thompson and Hannah 2010), and each group was counted separately. Total fecundity $\left(F_{t}\right)$ was estimated by the gravimetric method (Laevastu 1965, Bagenal and Braum 1971). The relations between fecundity and fork length and total weight were determined from the equations, $F=a L^{b}$ and $F=a+b W$, where $F$ is the number of eggs (fecundity), $L$ is fork length [cm], $W$ is total weight [g], and $a$ and $b$ are the constant parameters in the regression analysis. The percent contribution of each age group to total fecundity of the population was estimated iteratively.

\section{RESULTS}

In total, 344 Prussian carp individuals were caught during the study period. The sample comprised of 139 females and 193 males; 12 specimens were determined to be juveniles. The overall sex ratio was $1: 0.73$ (male : female) and differed significantly from parity $\left(\chi^{2}=8.78\right.$, $P<0.05$ ).

The Prussian carp population in Gelingüllü Reservoir was represented by six age groups, ranging from $0+$ years to $5+$ years (Fig. 1). Age groups $2+$ and $3+$ predominated, representing $46 \%$ and $36 \%$ of all specimens, respectively. Males were predominant in age groups $1+$, $2+$, and $3+$.

The relation between TL and FL was described by the equations:

for females and

$$
\mathrm{TL}=0.8014 \mathrm{FL}+0.9782\left(r^{2}=0.98\right)
$$

$$
\mathrm{TL}=0.7738 \mathrm{FL}+1.2736\left(r^{2}=0.96\right) \text { for males }
$$

FL in the Prussian carp ranged from 5.6 to $26.8 \mathrm{~cm}$ for females and from 6 to $27 \mathrm{~cm}$ for males. In juveniles minimum and maximum FL were 7.5 and $14.3 \mathrm{~cm}$, respectively. The length frequency distribution showed that there was a significant difference between males and females (ANOVA: $F=3.87, \mathrm{df}=1, P<0.05$ ) (Fig. 2).

Mean FL values were $5.6 \mathrm{~cm}$ at age $0+$ and $26 \mathrm{~cm}$ at age $5+$ in females, versus $6 \mathrm{~cm}$ at age $0+$ years and $27 \mathrm{~cm}$ at age $5+$ years for males (Fig. 3). There were no significant differences in mean length between males and females in any of the age groups.

Calculated von Bertalanffy growth parameters are presented in Table 1. According to Taylor (1962; cited after Grabowska et al. 2011), the maximum observed length should be approximately $95 \%$ of the estimated asymptotic length $\left(L_{\text {inf }}\right)$ (Grabowska et al. 2011). In the studied Prussian carp population, the maximum observed FL for males and females were 27 and $26.8 \mathrm{~cm}$, respectively. These values

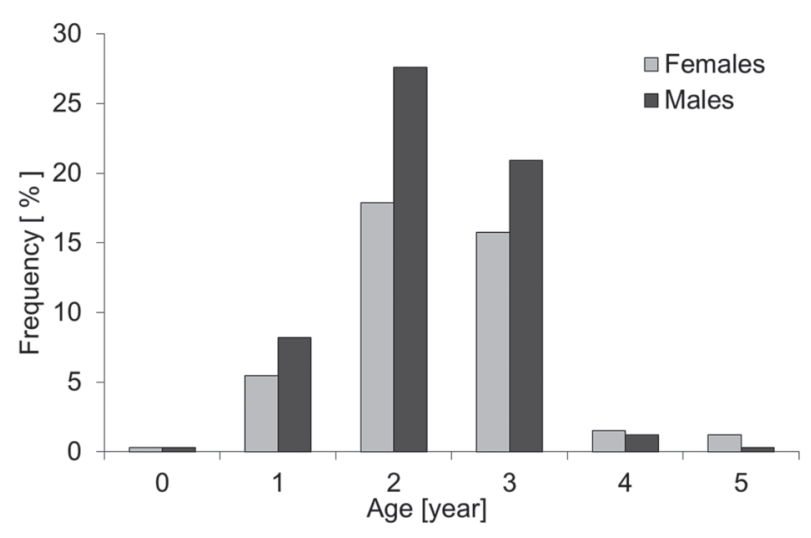

Fig. 1. Age structure of Prussian carp, Carassius gibelio, in the Gelingüllü Reservoir, Turkey

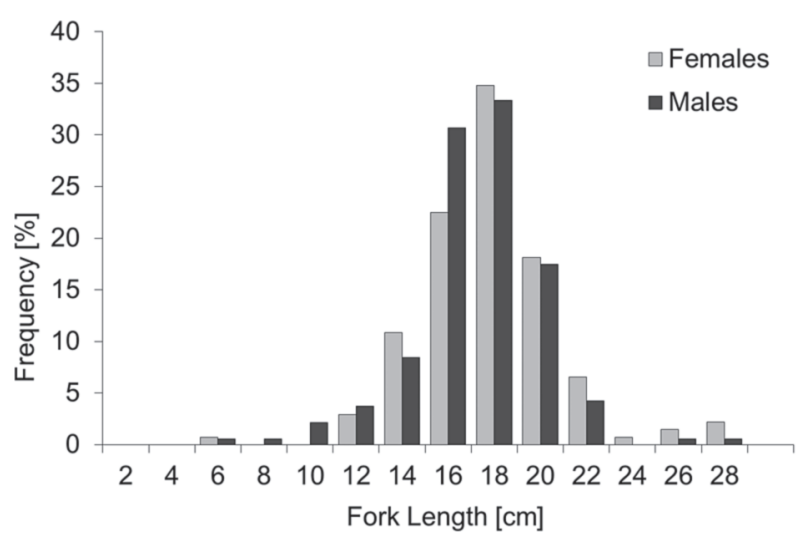

Fig. 2. Length frequencies of males and females of Prussian carp, Carassius gibelio, from Gelingüllü Reservoir, Turkey 
were $83.9 \%$ of males and $74.38 \%$ of females $L_{\text {inf. }}$ Therefore, the model was slightly overestimated for females.

Body weight of the specimens ranged from 3.8 to $597 \mathrm{~g}$ for females and from 4.3 to $539 \mathrm{~g}$ for males. In juveniles, weight ranged from 3.3 to $101.8 \mathrm{~g}$.

The regression of body weight on fork length revealed that there was a significant difference in the slope of regressions between the sexes (Student's $t$-test, $t=2.79$, $P<0.05$ ) (Table 2). The results given in Table 2 indicated that females grew isometrically and that there was no deviations from $b=3$ (Student's $t$-test, $t=0.88, P>0.05$ ), whereas negative allometric growth was observed in the males, with deviation from $b=3$ (Student's $t$-test, $t=3.68, P<0.05)$.

The annual specific growth rate decreased with age (Fig. 4): for females age $1+G_{L}$ was $85 \%$ and $G_{w}$ was $282 \%$, whereas $G_{L}$ and $G_{w}$ were $20 \%$ and $52 \%$ for females age $2+$. In males $G_{L}$ decreased from $70 \%$ at age $1+$ to $26 \%$ at age $2+$ and $G_{w}$ was $237 \%$ at age $1+$ and $70 \%$ at age $2+$.

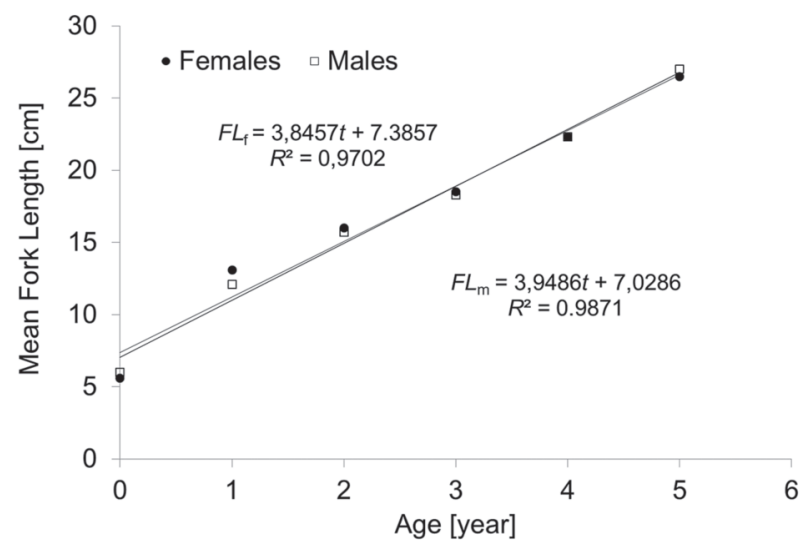

Fig. 3. Mean fork length (FL) at age in males (m) and females (f) of Prussian carp, Carassius gibelio, in Gelingüllü Reservoir, Turkey
After the first year of life the growth rate in females was lower than that in males.

The annual cycle of condition factor exhibited an almost similar pattern for both sexes (ANOVA: $F=70.74$, $\mathrm{df}=1, P<0.05)($ Table 3$)$. In both sexes there was a tendency for the condition factor to increase from spring to summer. The minimum mean $K$ was observed in March in males and in November in females. The mean peak value of $K$ was in June in males and in May and June in females. The condition in females was higher than that in males throughout the year.

Mean age at first maturity was 1.74 years in females and 1.42 years in males. Mean length at maturity in the males and females was $11.42 \mathrm{~cm}$ and $13.2 \mathrm{~cm}$, respectively.

The gonadosomatic index varied throughout the year (Table 3), but there were no significant difference between the males and females (ANOVA: $F=126.7 \mathrm{df}=1$, $P>0.001)$. In females mean GSI began to increase in March and attained 8.92 in April. Macroscopic analysis of gonads showed that $14.9 \%$ of the mature females spawned in April, when the mean water temperature was $11.7^{\circ} \mathrm{C}$. During this time individual GSI values in the female Prussian carp were highly variable, ranging from 0.38 to 15.8 , and both spawning and spawned females were observed simultaneously. In May and June mean GSI was 14.37 and 14.34, respectively, but sharply declined in July. Similar to the findings observed in April, mean GSI in the females during July was highly variable; approximately $70 \%$ of the mature females laid their eggs at this time. In males mean GSI was 3.73 in March and reached its maximum in June. After June mean GSI gradually decreased to its minimum in August. According to the monthly variation in mean GSI, a prolonged breeding period was observed from April until the end of July.

Ovaries simultaneously contained eggs of three different developmental stages-immature, maturing, and mature-especially during the breeding season (Fig. 5).

Table 1

Estimation of von Bertalanffy parameters and their asymptotic standard errors (in parentheses) for Prussian carp population from Gelingüllü Reservoir, Turkey

\begin{tabular}{lccccc}
\hline & $n$ & $L_{\text {inf }}$ & $k$ & $t_{0}$ & $r^{2}$ \\
\hline Males & 193 & $32.17(1.754)$ & $0.232(0.094)$ & 0.094 & 0.958 \\
Females & 139 & $36.03(2.255)$ & $0.212(0.139)$ & 0.205 & 0.916 \\
\hline
\end{tabular}

$n=$ number of specimens, $L_{\text {inf }}=$ asymptotic length, $k=$ relative growth coefficient, $t_{0}=$ theoretical age when fish length is zero, $r^{2}=$ determination coefficient.

Table 2

Descriptive statistics and length-weight relation parameters for males and females of Prussian carp population from Gelingüllü Reservoir, Turkey

\begin{tabular}{lccccccc}
\hline & $n$ & $a$ & SE $(a)$ & $b$ & SE $(b)$ & $r^{2}$ & $P$ \\
\hline Males & 193 & -1.40 & 0.060 & 2.80 & 0.04 & 0.94 & $<0.05$ \\
Females & 139 & -1.64 & 0.071 & 3.05 & 0.06 & 0.95 & $<0.05$ \\
\hline
\end{tabular}

$n=$ number of specimens, $\mathrm{SE}=$ standard error, $a=$ intercept of the regression line, $b=$ regression coefficient, $r^{2}=$ determination coefficient, $P=P$-value. 
Egg diameter ranged from $0.90 \mathrm{~mm}$ to $1.51 \mathrm{~mm}$ in mature eggs, from 0.70 to $0.88 \mathrm{~mm}$ in maturing eggs, and from 0.30 to $0.70 \mathrm{~mm}$ in immature eggs.

Estimation of fecundity was complicated because small (immature) oocytes predominated throughout the year (Fig. 5); however, assuming that all oocytes could mature during the spawning season total fecundity $\left(F_{t}\right)$ was considered as the number of all oocytes in ovaries. Oocytes in the previtellogenic phase of development can be a reservoir of reproductive cells for subsequent years. The smallest female with mature eggs had FL of $12 \mathrm{~cm}$ and weighed $49 \mathrm{~g}$ at age $1+; F_{t}$ in this female was 8544 . The maximum individual fecundity value, with 174057 eggs, was observed in a female aged $4+$ years that had FL of $22 \mathrm{~cm}$ and weighed $287.4 \mathrm{~g}$. $F_{t}$ was related to female fork length and body weight, based on the equations:

$$
F_{t}=0.434 \mathrm{FL}^{3.767}\left(r^{2}=0.412\right)
$$

and

$$
F_{t}=239.9 \mathrm{~W}-10.858,\left(r^{2}=0.533\right),
$$

respectively. Fecundity was not strongly associated with body length or weight, as is expected in multi-spawners. Mean $F_{t}$ increased gradually as the spawning period progressed, as seen in Table 3.
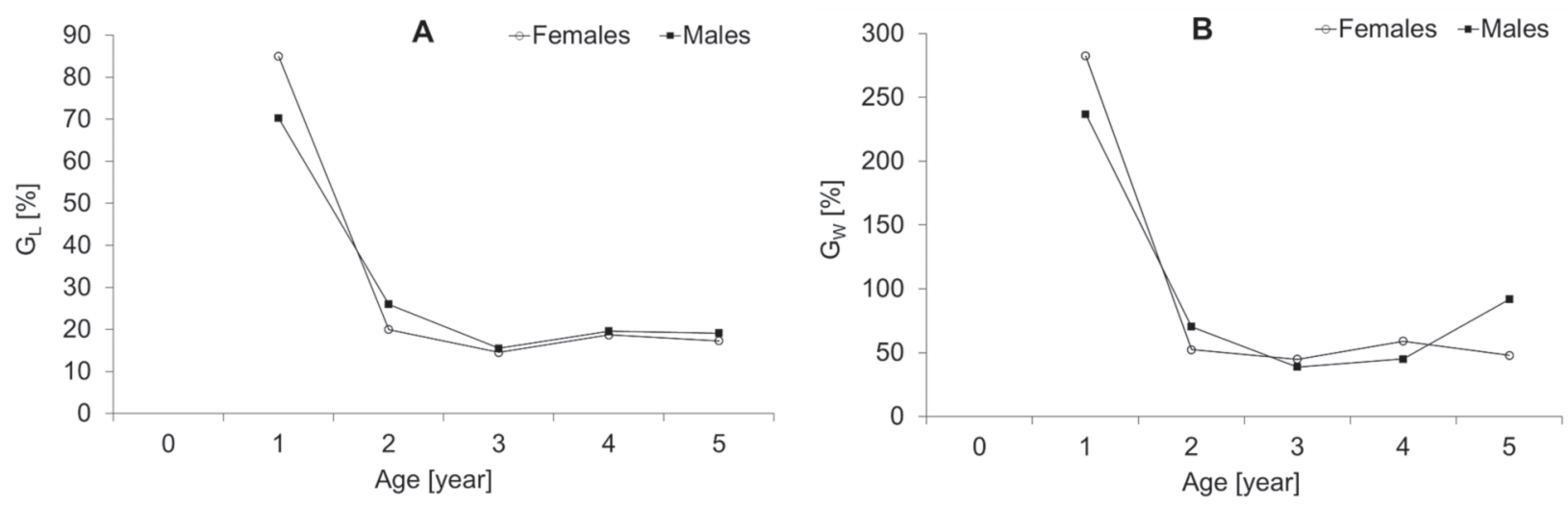

Fig. 4. Growth rates in length $\left(G_{L} ; \mathbf{A}\right)$ and weight $\left(G_{W} ; \mathbf{B}\right)$ of Prussian carp, Carassius gibelio, from Gelingüllü Reservoir, Turkey

Table 3

Monthly variation in condition factor, gonadosomatic index, and mean fecundity of Prussian carp population from

\begin{tabular}{|c|c|c|c|c|c|}
\hline \multirow{2}{*}{ Month } & \multicolumn{2}{|c|}{$K$} & \multicolumn{2}{|c|}{ GSI } & \multirow{2}{*}{ Mean $F_{t}$} \\
\hline & Female & Male & Female & Male & \\
\hline March & $2.35(0.21)$ & $2.12(0.32)$ & $8.40(2.43)$ & $3.73(0.92)$ & 22959 \\
\hline April & $2.52(0.36)$ & $2.24(0.28)$ & $8.92(4.40)$ & $3.66(1.35)$ & 29472 \\
\hline May & $2.77(0.36)$ & $2.38(0.44)$ & $14.37(4.11)$ & $5.35(1.55)$ & 56863 \\
\hline June & $2.77(0.26)$ & $2.41(0.33)$ & $14.34(5.62)$ & $5.78(1.83)$ & 76612 \\
\hline July & $2.68(0.34)$ & $2.27(0.28)$ & $3.86(3.58)$ & $3.15(1.53)$ & 9416 \\
\hline August & $2.50(0.23)$ & $2.15(0.21)$ & $0.9(0.48)$ & $2.07(0.70)$ & \\
\hline September & $2.46(0.31)$ & $2.33(0.07)$ & $3.18(2.56)$ & $3.31(1.69)$ & \\
\hline October & $2.34(0.12)$ & $2.33(0.31)$ & $3.86(1.56)$ & $4.03(1.24)$ & \\
\hline November & $2.32(0.15)$ & $2.27(0.31)$ & $5.58(1.65)$ & $3.78(0.90)$ & \\
\hline
\end{tabular}
Gelingüllü Reservoir, Turkey

Values in parentheses are standard deviations; $K=$ condition factor, GSI $=$ gonadosomatic index, $F_{t}=$ total fecundity.

The $3+$ years age group contributed the highest percent-

\section{DISCUSSION}

During our previous studies on carp in Gelingüllü servoir we observed that approximately 20 adult the reservoir by a local fisherman (Kirankaya and Ekmekçi 2004). The other possible origin of this species Prussian carp was detected following carp introduction practices (Copp et al. 2005), as in many reservoirs in (ne oldest Prussian carp tion. The age structure of Prussian carp specimens from Gelingüllü Reservoir was similar to that observed in natural lakes and reservoirs in Turkey (Table 5). Although some records of Prussian carp from European freshwaters have a long lifespan of between 10 and 11 years (Szczerbowski 2001), in Turkish inland waters the maxi.

.


mum is up to 9 years (Özkök et al. 2007). The most numerous age groups observed in the presently reported study were $2+$ and $3+$ (approximately $80 \%$ of the total), as observed in many European (Szczerbowski 2001) and Turkish populations (Balık et al. 2004, Sarı et al. 2008, Emiroğlu unpublished*). The high fecundity observed in the females in the presently reported study $3+$ years age group made a special contribution to the population (Table 4). Prussian carp is not a commercially valuable species for fisheries in Gelingüllü Reservoir and it was incidentally caught by gill nets varying in mesh size that are used for other species. Thus, selectivity of fishing gear did not appear to have any effect on the age structure of Prussian carp.

Maximum FL and $W$ in Prussian carp was approximately $27 \mathrm{~cm}$ and $597 \mathrm{~g}$, respectively, in this study. Although there were fewer age groups in the studied population, as compared to European populations, maximum length and body weight were similar to $26 \mathrm{~cm}$ and $750 \mathrm{~g}$ reported by Szczerbowski (2001). Tsoumani et al. (2006) found that fork length in Prussian carp specimens from 12 different lakes in Greece ranged from 14.5 to $37.7 \mathrm{~cm}$. Prussian carp can attain fork length of $33 \mathrm{~cm}$ and weight of $873 \mathrm{~g}$ in Turkey (Balık et al. 2004, Emiroğlu unpublished*). According to the von Bertalanffy model, females in the presently reported study were slightly larger than males and the asymptotic length $\left(L_{i n f}\right)$ in females was greater than that in males.

The length-weight relation observed in this study also suggested that there was a difference in growth between sexes; negative allometric growth was observed in males, whereas females grew isometrically. Negative allometry appears to be a common pattern in Prussian carp, as reported by Tsoumani et al. (2006).

Additional differences observed in growth parameters between males and females in the presently reported study are supported by the specific growth rate. During the first year of life the specific growth rate in length was approximately $85 \%$ for females and $70 \%$ for males. These high values decreased sharply after sexual maturity was attained. Similarly, the rate of weight increase was higher

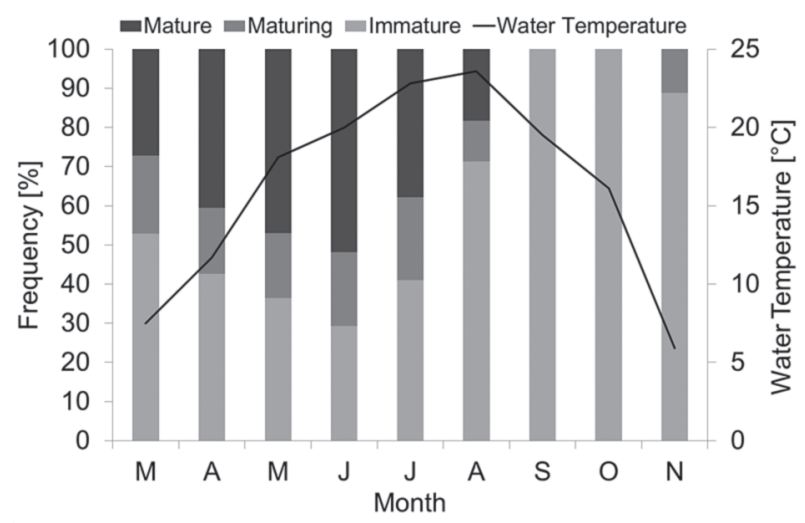

Fig. 5. Frequency of eggs at different developmental stage in ovaries of Prussian carp, Carassius gibelio, from Gelingüllü Reservoir, Turkey in the females (282\% for females and $237 \%$ for males) during the first year of life. It is known that such an accelerated growth rate allows the fish to attain early maturity (Tarkan 2006, Grabowska et al. 2011); thus, the annual increase in growth diminishes sharply after sexual maturity. A high growth rate during the first year was observed in fish species that mature early (Nikolsky 1963). In Prussian carp populations a high growth rate during the first year of life may be an adaptation for increasing fitness rapidly.

Both the length-age relation (Table 5) and von Bertalanffy growth equations (Balık et al. 2004, Çınar et al. 2007, Özkök et al. 2007, Sarı et al. 2008, Emiroğlu unpublished*) showed that Prussian carp in the Gelingüllü Reservoir grew slower than the majority of other populations in Turkey. Although the species exhibits a higher growth rate in artificial water bodies in Turkey (Tarkan et al. 2012a), the lower growth rate observed in the presently reported study was likely due to differences in climate, food resources, density-dependent factors, and possible competition for food with other carp. Moreover, Tsoumani et al. (2006) reported that Prussian carp exhibits good growth performance in mesotrophic and oligotrophic lakes. Gelingüllü Reservoir is mesotrophic in character (unpublished data by Kırankaya), but we also know that the growth rate of Prussian carp markedly decreases in areas densely stocked with carp (Szczerbowski 2001); therefore, the observed lower growth rate of Prussian carp in Gelingüllü Reservoir might have been due to its location at $1050 \mathrm{~m}$. above sea level and its dense mirror- and scaled carp stocks.

The somatic condition cycle $(K)$ varied according to season in the present study; the lowest values were recorded in early spring and autumn. As the water temperature increased in spring, and feeding activity and gonadal maturation started, $K$ increased to its maximum value in May and June. At the end of summer when spawning terminated, the condition factor in the Prussian carp gradually decreased.

The male to female ratio in the present sample of Prussian carp differed significantly from parity (in overall specimens $1: 0.73$ ). In Prussian carp gonad differentiation takes place between 60 and 70 days and sex differentiation

Table 4

Mean fecundity and percentage contribution by age group to total number of released eggs in Prussian carp population from Gelingüllü Reservoir, Turkey

\begin{tabular}{cccc}
\hline Age & $n$ & $F_{\mathrm{M}}$ & $\% F_{\mathrm{t}}$ \\
\hline $1+$ & 6 & 4993 & 0.70 \\
$2+$ & 36 & 34327 & 30.6 \\
$3+$ & 38 & 62318 & 55.8 \\
$4+$ & 2 & 130475 & 12.9 \\
\hline
\end{tabular}

$n=$ number of specimens, $F_{\mathrm{M}}=$ mean fecundity, $F_{\mathrm{t}}=$ total fecundity. 
terminates at 120 days after hatching (Bieniarz 1986); therefore, sex was determined in the present study without any doubt, even in some individuals in the $0+$ year group. Indeed, a pronounced female bias in the sex ratio is quite common in Prussian carp populations (Szczerbowski 2001). Gynogenesis is the commonly known reproduction strategy for Prussian carp, and females significantly outnumber males in the majority of populations (Vetemaa et al. 2005, Bostanc1 et al. 2007, Sar1 et al. 2008, Leonardos et al. 2008, Liasko et al. 2011, Tarkan et al. 2012a), whereas bisexual populations are also observed (Szczerbowski 2001). Abundance of males in Gelingüllü Reservoir suggested that this population is probably bisexual. Indeed, reproduction mode of Prussian carp population in Gelingüllü Reservoir could be accurately determined by genetic investigations.

In Gelingüllü Reservoir both males and females attained sexual maturity the year following hatching. Szczerbowski (2001) reported that Prussian carp attains sexual maturity at age $3+, 4+$, and $5+$ according to latitude in its range of occurrence, and at age $2+$ in Romania, however, in the studied population both sexes reached maturity after the first year of life as observed in many Prussian carp population in Turkey (Tarkan et al. 2012a, b). Early maturity is one of the most important characteristics of invasive species, which ensures establishment of a sustainable population in new environments (Rosecchi et al. 1993, Yang 1996, Vila-Gispert et al. 2005). On the other hand, according to life history theory, the cost of early maturity is a reduction in lifespan (Oliva-Paterna et al. 2002). Early sexual maturity in the present Prussian carp population might explain its success and short life span.

The spawning season in the studied population was longer than that recorded for Prussian carp in its natural range, in which reproduction begins by the end of May or during June at a water temperature of $18-19^{\circ} \mathrm{C}$ (Szczerbowski 2001); however, in the presently reported study it began in April, when the water temperature in Gelingüllü Reservoir was $11.7^{\circ} \mathrm{C}$. Paschos et al. (2004) observed a short spawning period in the Pamvotis Lake population between March and April at a water temperature of $12-14^{\circ} \mathrm{C}$, but for introduced Prussian carp populations in Turkey the duration of the spawning season is reported to last 3-4 months (Balık et al. 2004, Tarkan et al. 2006, Emiroğlu unpublished*), as observed in the present study. The breeding season in fish species depends on several environmental factors such as photoperiod and water temperature (Wootton 1990); hence, populations of a species in different geographic locations may exhibit differences in their breeding period. On the other hand, the prolonged spawning period is a key characteristic of multiple spawners (Rinchard and Kestemont 1996).

The size frequency distribution of oocytes remained polymodal throughout the year in the presently reported study. Ovaries contained oocytes at different stages of development (mature, maturing, and immature), indicating that the females could spawn several times during the reproductive period. Such asynchronous oocyte development classifies this fish as a multi-spawner. Indeed, Prussian carp is a multiple spawner and females release 2-3 batches of eggs each year (Muus and Dahlström 1981, Szczerbowski 2001). Successful invaders have asynchronous gonad (oocyte) development and multiple spawning properties (Bogutskaya and Naseka 2002, Vila-Gispert et al. 2005). The multiple spawning strategy has advantages in fluctuating environments, as all progeny are not at risk during one reproductive event, when a climatic change could destroy all offspring in a given year (Oliva-Paterna et al. 2002). Although ovaries were observed to be asynchronous in the presently reported study, as there were oocytes in different stages of vitellogenesis, three maturation cycles of yolky eggs were noted. Thus, a female could spawn at least two batches of eggs per breeding season. Both the GSI values and our observations on development of eggs revealed that the Prussian carp in the present study had a short gonadal quiescent period. Development of gonads in autumn may be an advantageous strategy for a species; thus, fish spawn early in spring (Rinchard and Kestemont 1996).

Table 5

Length at age data for various Prussian carp population in Turkey

\begin{tabular}{|c|c|c|c|c|c|c|c|c|c|c|c|c|}
\hline \multirow{2}{*}{ Location } & \multirow{2}{*}{ Length } & \multicolumn{10}{|c|}{ Mean observed length at ages } & \multirow{2}{*}{ Source } \\
\hline & & A0 & A1 & $\mathrm{A} 2$ & A3 & A4 & A5 & A6 & A7 & A8 & A9 & \\
\hline Lake Eğirdir & FL & & 11.9 & 18.1 & 22.9 & 25.5 & 27.4 & 29.6 & & & & Balık et al. 2004 \\
\hline Buldan Reservoir & FL & & 11.66 & 14.13 & 16.98 & 18.89 & 20.26 & 22.03 & & & & Sar1 et al. 2008 \\
\hline Lake İznik & $\mathrm{TL}$ & & 13.75 & 19.67 & 25.33 & 30.05 & & & & & & Tarkan et al. 2006 \\
\hline Ömerli Reservoir & $\mathrm{TL}$ & & 12.61 & 20.41 & 26.74 & 30.88 & 33.12 & 35.7 & & & & Tarkan et al. 2006 \\
\hline Topçam Reservoir & FL & & & & 23.8 & 25.48 & 27.01 & 28.38 & & & & Şaş1 2008 \\
\hline Lake Beyşehir & FL & 9.2 & 12.0 & 19.6 & 22.1 & 24.3 & 26.7 & & & & & Çınar et al. 2007 \\
\hline Lake Eğirdir & FL & 9.46 & 11.96 & 18.62 & 21.82 & 24.41 & 26.86 & 28.67 & 30.57 & 31.02 & 32.6 & Özkök et al. 2007 \\
\hline Lake Uluabat & $\mathrm{TL}$ & & 17.61 & 23.07 & 25.87 & 28.87 & 31.25 & 31.93 & 33.20 & & & Emiroğlu unp.* \\
\hline Gelingüllü Res. & FL & 6.37 & 12.6 & 15.8 & 18.4 & 22.3 & 26.6 & & & & & This study \\
\hline
\end{tabular}

$\mathrm{FL}=$ fork length, $\mathrm{TL}=$ total length.

\footnotetext{
* See footnote on page 36.
} 
Mean $F_{t}$ reached up to 130000 in the population studied. According to Szczerbowski (2001), the fecundity in Prussian carp in ponds varies from 3000 to 205000 . Individual fecundity values exceeded 174000 and it was higher, in relation to other Prussian carp populations in Turkey (Balık et al. 2004, Tarkan et al. 2006). The observed fecundity values indicate that the Prussian carp established a very fecund population in the Gelingüllü Reservoir. On the other hand, mean fecundity increased as the spawning period progressed, suggesting that there was recruitment from the stock of the immature eggs.

Although the spawning season was between April and July, spawning occurred mostly during May and June, which is supported by both GSI and the ratio of mature eggs to total eggs.

The Gelingüllü Reservoir Prussian carp population was characterized by rapid growth, early maturity, a high level of reproductive effort, and a short life span. These life history characteristics are typical of populations in unstable environments, in which adult mortality is high, variable, or unpredictable (Fernández-Delgado and Herrera 1995). The species benefits from producing many offspring early in life, because both factors contribute to a higher rate of population increase. The corresponding cost of reduced capacity for future reproduction is minimized, because adult survival is low by default. Prussian carp are able to expand their range of distribution through various biological mechanisms, ecological plasticity, and a high tolerance for unfavourable environmental conditions.

\section{ACKNOWLEDGEMENTS}

This research was funded by the Hacettepe University Research Center (project no. 07-D-03601002) and was part of Ş.G. Kırankaya's PhD thesis that was submitted in 2007 and supervised by F.G. Ekmekçi.

\section{REFERENCES}

Bagenal T.B., Braum E. 1971. Eggs and early life history. Pp.166-198. In: Ricker W.E. (ed.) Methods for assesment of fish production in fresh waters. Blackwell Scientfic Publications, Oxford, UK.

Balık İ., Özkök R., Çubuk H., Uysal R. 2004. Investigation of some biological characteristics of the silver crucian carp, Carassius gibelio (Bloch 1782) population in Lake Eğirdir. Turkish Journal of Zoology 28 (1): 19-28.

Bieniarz K. 1986. Sex differantion and puberty in cyprinids. Pp. 101-108. In: Billard R., Marcel J. (eds.) Aquaculture of cyprinids. INRA, Paris.

Bogutskaya N.G., Naseka A.M. 2002. An overview of nonindigenous fishes in inland waters of Russia. Zoological Sessions (Annual Reports 2001) Proceedings of the Zoological Institute of Russian Academy of Science 296: 21-30.

Bostancı D., Polat N., Kandemir Ş., Yılmaz S. 2007. Bafra Balık Gölü'nde yaşayan havuz balığı Carassius gibelio (Bloch, 1782)'nun kondisyon faktörü ve boy-ağırlık ilişkisinin belirlenmesi. [Determination of condition factor and length-weight relationship of the crucian carp, Carassius gibelio (Bloch, 1782) inhabiting Bafra Fish Lake]. SDÜ Fen Edebiyat Fakültesi Fen Dergisi 2 (2): 117-125. [In Turkish.]

Copp G.H., Bianco P.G., Bogutskaya N.G., Erös T., Falka I., Ferreira M.T., Fox M.G., Freyhof J., Gozlan R.E., Grabowska J., Kováč V., Moreno-Amich R., Naseka A.M., Peňáz M., Povž M., Przybylski M., Robillard M., Russell I.C., Stakėnas S., Šumer S., Vila-Gispert A., Wiesner C. 2005. To be, or not to be, a non-native freshwater fish? Journal of Applied Ichthyology 21 (4): 242-262. DOI: 10.1111/j.14390426.2005.00690.x

Crivelli A.J. 1995. Are fish introductions a threat to endemic freshwater fishes in the northern Mediterranean region? Biological Conservation 72 (2): 311-319. DOI: 10.1016/0006-3207(94)00092-5

Çınar Ş., Çubuk H., Özkök R., Tümgelir L., Çetinkaya S., Erol K.G., Ceylan M. 2007. Beyşehir Gölü’ndeki gümüşi havuz balığı (Carassius gibelio Bloch, 1782) populasyonunun büyüme özellikleri. [Growth features of silver crucian carp (Carassius gibelio Bloch, 1782) population in Lake Beyşehir.] Türk Sucul Yaşam Dergisi 3-5 (5-8): 401-409. [In Turkish.]

Fernández-Delgado C., Herrera M. 1995. Age structure, growth and reproduction of Rutilus lemmingii in an intermittent stream of the Guadalquivir river basin, southern Spain. Hydrobiologia 299 (3): 207-213. DOI: 10.1007/BF00767327

Froese R., Pauly D. (eds.) 2012. FishBase. [version 06/2012] http://www.fishbase.org

García-Berthou E. 2007. The characteristics of invasive fishes: what has been learned so far? Journal of Fish Biology 71 (Supplement sd): 33-55. DOI: 10.1111/j.10958649.2007.01668.x

Gaygusuz Ö., Tarkan A.S., Gürsoy Gaygusuz Ç. 2007. Changes in the fish community of the Ömerli Reservoir (Turkey) following the introduction of non-native gibel carp Carassius gibelio (Bloch, 1782) and other human impacts. Aquatic Invasions 2 (2): 117-120. DOI: 10.3391/ai.2007.2.2.6

Grabowska J., Pietraszewski D., Przybylski M., Tarkan A.S., Marszał L., Lampart-Kałużniacka M. 2011. Life-history traits of Amur sleeper, Perccottus glenii, in the invaded Vistula River: early investment in reproduction but reduced growth rate. Hydrobiologia 661 (1): 197-210. DOI: 10.1007/s10750-010-0524-0

İlhan A., Balık S., Sarı H.M., Ustaoğlu M.R. 2005. Batı ve Orta Anadolu, Güney Marmara, Trakya ve Batı Karadeniz Bölgeleri İçsularındaki Carassius (Cyprinidae, Pisces) Türleri ve Dağılımları. [Carassius (Cyprinidae, Pisces) species in inland waters of Western and Middle Anatolia, Southern Marmara, Thrace and Western Black Sea Regions and their distributions.] Ege University Journal of Fisheries and Aquatic Sciences 22 (3-4): 343-346. [In Turkish.]

Kalous L., Bohlen J., Rylková K., Petrtýl M. 2012. Hidden diversity within the Prussian carp and designation of a neotype for Carassius gibelio (Teleostei: Cyprinidae). Ichthyological Exploration of Freshwaters 23 (1): 11-18.

Kalous L., Memiş D., Bohlen J. 2004. Finding of triploid Carassius gibelio (Bloch, 1780) (Cypriniformes, Cyprinidae) in Turkey. Cybium 28 (1): 77-79. 
Kalous L., Šlechtová V. Jr., Bohlen J., Petrtýl M., Švátora M. 2007. First European record of Carassius langsdrofii from the Elbe basin. Journal of Fish Biology 70 (Supplement sa): 132-138. DOI: 10.1111/j.1095-8649.2006.01290.x

Kırankaya Ş.G., Ekmekçi F.G. 2004. Growth properties of mirror carp (Cyprinus carpio L., 1758) introduced into Gelingüllü Dam Lake. Turkish Journal of Veterinary and Animal Science 28 (6): 1057-1064.

King M. 1996. Fisheries biology, assessment and management. Fishing News Books, Malden, MA, USA.

Kottelat M., Freyhof J. 2007. Handbook of European freshwater fishes. Kottelat, Cornol, Switzerland and Freyhof, Berlin, Germany.

Laevastu T. (ed.) 1965. Manual of methods in fisheries biology. FAO Manuals in Fisheries Science No. 1.

Lagler K.F. 1966. Freshwater fishery biology. WMC Brown Company, Dubuque, IA, USA.

Leonardos I.D., Tsikliras A.C., Eleftheriou V., Cladas Y., Kagalou I., Chortatou R., Papigioti O. 2008. Life history characteristics of an invasive cyprinid fish (Carassius gibelio) in Chimaditis Lake (northern Greece). Journal of Applied Ichthyology 24 (2): 213-217. DOI: 10.1111/j.14390426.2007.01031.x

Liasko R., Koulish A., Pogrebniak A., Papiggioti O., Taranenko L., Leonardos I. 2011. Influence of environmental parameters on growth pattern and population structure of Carassius auratus gibelio in eastern Ukraine. Hydrobiologia 658 (1): 317-328. DOI: 10.1007/s10750010-0502-6

Muus B.J., Dahlström P. 1981. Guide des poissons d'eau douce et pêche. Delachaux et Niestlé, Paris, France, Neuchâtel, Switzerland.

Nikolsky G.V. 1963. The ecology of fishes (Translated by L. Birkett), Academic Press, London.

Oliva-Paterna F.J., Torralva M.M., Fernández -Delgado C. 2002. Age, growth and reproduction of Cobitis paludica in a seasonal stream. Journal of Fish Biology 60 (2): 389-404. DOI: $10.1006 /$ jfbi.2001.1851

Özkök R., Çubuk H., Tümgelir L., Uysal R., Çınar Ş., Küçükkara R., Erol G.K., Ceylan M. 2007. Eğirdir Gölü’ndeki gümüşi havuz balığı (Carassius gibelio Bloch, 1782) populasyonunun büyüme özellikleri. [Growth features of silver crucian carp (Carassius gibelio Bloch, 1782) population in Lake Eğirdir.] Türk Sucul Yaşam Dergisi 3-5 (5-8): 313-321. [In Turkish.]

Özuluğ M., Acıpınar H., Gaygusuz Ö., Gürsoy Ç., Tarkan, A.S. 2005a. Effects of human factor on the fish fauna in a drinking-water resource (Ömerli Dam Lake-İstanbul, Turkey). Research Journal of Agriculture and Biological Sciences 1 (1): 50-55.

Özuluğ M., Altun Ö., Meriç N. 2005b. On the fish fauna of Lake İznik (Turkey). Turkish Journal of Zoology 29 (4): 371-375.

Özuluğ M., Meriç N., Freyhof J. 2004. The distribution of Carassius gibelio (Bloch, 1782) (Teleostei: Cyprinidae) in Thrace (Turkey). Zoology in the Middle East 31: 63-66.

Paschos I., Nathanailides C., Tsoumani M., Perdikaris C., Gouva E., Leonardos, I. 2004. Intra and inter-specific mat- ing options for gynogenetic reproduction of Carassius gibelio (Bloch, 1783) in Lake Pamvotis (NW Greece). Belgian Journal of Zoology 134 (1): 55-60.

Ribeiro F., Elvira B., Collares-Pereira M.J., Moyle P.B. 2008. Life-history traits of non-native fishes in Iberian watersheds across several invasion stages: a first approach. Biological Invasions 10 (1): 89-102. DOI: 10.1007/s10530-007-9112-2

Rinchard J., Kestemont P. 1996. Comperative study of reproductive biology in single- and multiple-spawner cyprinid fish. I. Morphological and histological features. Journal of Fish Biology 49 (5): 883-894. DOI: 10.1111/j.10958649.1996.tb00087.x

Rosecchi E., Crivelli, A.J., Catsadorakis G. 1993. The establishment and impact of Pseudorasbora parva, an exotic fish species introduced into Lake Mikri Prespa (north-wester Greece). Aquatic Conservation: Marine and Freshwater Ecosystems 3 (3): 223-231. DOI: 10.1002/aqc.3270030306

Sarı H.M., Balık S., Ustaoğlu R., İlhan A. 2008. Population structure, growth and mortality of Carassius gibelio (Bloch, 1782) in Buldan Dam Lake. Turkish Journal of Fisheries and Aquatic Sciences 8 (1): 25-29.

Szczerbowski J.A. 2001. Carassius Jarocki, 1822. Pp. 1-78. In: Bănărescu P.M., Paepke H.J. (eds.) The freshwater fishes of Europe. Vol. 5. Cyprinidae 2. Part 3. Carassius to Cyprinus. Gasterosteidae. Aula-Verlag, Wiebelsheim, Germany.

Şaşı H. 2008. The length and weight relations of some reproduction characteristics of Prussian carp, Carassius gibelio (Bloch, 1782) in the South Aegean Region (Aydın-Turkey). Turkish Journal of Fisheries and Aquatic Sciences 8 (1): 87-92.

Şaşı H., Balık, S. 2003. The distribution of three exotic fishes in Anatolia. Turkish Journal of Zoology 27 (4): 319-322.

Takada M., Tachihara K., Kon K., Yamamato G., Iguchi K., Miya M., Nishida M. 2010. Biogeography and evolution of the Carassius auratus-complex in East Asia. BMC Evolutionary Biology 10 (7): 1-18. DOI: 10.1186/14712148-10-7

Tarkan A.S., Copp G., Top N., Özdemir N., Önsoy B., Bilge G., Filiz H., Yapıcı S., Ekmekçi F.G., Kırankaya Ş.G., Emiroğlu Ö., Gaygusuz O., Gürsoy Gaygusuz C., Oymak A., Özcan G., Saç G. 2012a. Are introduced gibel carp Carassius gibelio in Turkey more invasive in artificial than in natural waters? Fisheries Management and Ecology 19 (2): 178-187. DOI: 10.1111/j.1365-2400.2011.00841.x

Tarkan A.S., Gaygusuz Ö., Gürsoy Ç., Acıpınar H., Bilge G. 2006. Marmara Bölgesi'nde yeni bir istilac1 tür Carassius gibelio (Bloch, 1782): Başarılı mı, Başarısız mı? [A new invasive species Carassius gibelio (Bloch, 1782) in Marmara Region: successful or unsuccesful?] Pp. 193-203. In: 1. Ulusal Balıklandırma ve Rezervuar Yönetimi Sempozyumu, 7-9 February 2006, Antalya, Turkey. [In Turkish.]

Tarkan A.S., Gaygusuz Ö., Gürsoy Gaygusuz Ç., Saç G., Copp G. 2012b. Circumstantial evidence of gibel carp, Carassius gibelio, reproductive competition exerted on native fish species in a mesotrophic reservoir. Fisheries Management and Ecology 19 (2): 167-177. DOI: 10.1111/j.1365-2400.2011.00839.x

Thompson J.E., Hannah R.W. 2010. Using cross-dating techniques to validate ages of aurora rockfish (Sebastes aurora): 
estimates of age, growth and female maturity. Wootton R.J. 1990. Ecology of teleost fishes. Chapman and Environmental Biology of Fishes 88 (4): 377-388. DOI: 10.1007/s10641-010-9653-6 Hall, London, UK.

Tsoumani M., Liasko R., Moutsaki P., Kagalou I., Leonardos I. 2006. Length-weight relationships of an invasive cyprinid fish (Carassius gibelio) from 12 Greek lakes in relation to their trophic states. Journal of Applied Ichthyology 22 (4): 281-284. DOI: 10.1111/j.1439-0426.2006.00768.x

Vetemaa M., Eschbaum R., Albert A., Saat T. 2005. Distribution, sex ratio and growth of Carassius gibelio (Bloch) in coastal and inland waters of Estonia (north-eastern Baltic Sea). Journal of Applied Ichthyology 21 (4): 287-291. DOI: 10.1111/j.1439-0426.2005.00680.x

Vila-Gispert A., Alcaraz C., García-Berthou E. 2005. Lifehistory traits of invasive fish in small Mediterranean streams. Biological Invasions 7 (1): 107-116. DOI: 10.1007/s10530-004-9640-y

Received: 25 July 2012

Accepted: 8 December 2012

Published electronically: 31 March 2013 Pp. 157-168 In: Peter J.S., Wnag S., Xie Y. (eds.) Conserving China's Biodiversity (II). China Environmental Science Press, Beijing, China.

Zar J.H. 1999. Biostatistical analysis. 4th edn. Prentice-Hall International, Upper Saddle River, NJ, USA. 